\title{
The usefulness of GGE biplot methodology for line $\times$ tester data of maize inbred lines
}

\author{
Hossein Momeni1 (iD, Mohammadreza Shiri2* (D), Eslam Majidi Hervan¹ (D), Mahmoud Khosroshahli ${ }^{1}$ (D) \\ 1. Department of Biotechnology and Plant Breeding - Science and Research Branch - Islamic Azad University - Tehran, Iran. \\ 2. Seed and Plant Improvement Institute - Agricultural Research, Education and Extension Organization - Karaj, Iran.
}

\begin{abstract}
The genotype + genotype $\times$ environment (GGE) biplot methodology has the potential to determine combining ability effects, identify efficient testers, and distinct heterotic groups in a line $x$ tester study. However, it has not been adequately applied for such analysis. Therefore, this study was done to assess the combining ability of some maize inbred lines and testers for grain yield, identify most efficient testers and classify inbred lines into heterotic groups using GGE biplot. Fifteen experimental single cross hybrids, generated from a $5 \times 3$ line by line $\times$ tester crosses procedure, were evaluated across seven sites in Iran in 2018 using a randomized complete block design with three replicates per entry at each site. According to the pooled analysis of variance, crosses showed significant differences for grain yield. Also, the differences observed among the testers, inbred lines, and interactions for the line $\times$ tester, crosses $\times$ environments, line $\times$ tester $\times$ environment was significant. The inbred line L4 was recognized as outstanding for its general combining ability (GCA) effect and the tester K18 was highly efficient based on its discriminating power. It can be concluded that the crosses of $L 4 \times K 47 / 3$ and $L 4 \times B 73$ are suggested to release high grain yield hybrids. Results of the GGE biplot analyses were close to the conventional line $\times$ tester method in combining ability and heterotic patterns of the yield of lines, grouping, and identification of testers.
\end{abstract}

Key words: combining ability, heterotic, polygon, grain yield.
Received:

Mar. 31, 2020

Accepted:

Jul. 21, 2020

Section Editor:

Gabriel Constantino Blain

${ }^{*}$ Corresponding author: mohammadrezashiri52@gmail.com

\section{INTRODUCTION}

Maize (Zea mays L.) is a widely grown crop in most parts of the world due to its adaptability and productivity. It is one of the most important crops in Iran, accounting for over 4.13\% of its total cropped area (Shiri et al. 2014).

To improve maize grain yield, it is essential to have certain information on the nature of both general and specific combining ability (GCA, SCA) of candidate parents, used in hybridization. Combining ability analysis is a powerful tool to select the most desirable parental lines to release superior hybrids. The success in the hybridization programs strongly depends on the ability of the parents to perform desirable combinations. The additive and nonadditive gene effects are distinguished by GCA and SCA, respectively (Nevado and Cross 1990). Understanding the type of gene action involved in the expression of the traits is necessary to choose an efficient breeding program. In the case of involving additive gene action, standard selection procedures would be favorable to make a desirable change in the intended character in a breeding program, whereas the production of hybrids would be more effective in the case of the involvement of dominant gene action (Edwards et al. 1976).

Numerous researches have been performed on combining ability and heterosis, most of these researches have shown significant effects of GCA and SCA on grain yield in maize suggesting that both additive and non-additive gene action play a crucial role in the inheritance of this trait (Iqbal et al. 2007; Malvar et al. 1996; Shiri et al. 2010; Shiri 2017; Shiri and Ebrahimi 2017). 
Biparental, multiple crosses, test crosses, line $\times$ tester, and diallel designs can be listed as the most commonly used breeding designs for determining the combining abilities of parental lines and experimental crosses (Nduwumuremyi et al. 2013). The line $\times$ tester approach is widely used in breeding both self and cross-pollinated crops to identify the most desirable parents. Despite different applications of breeding designs, their general problem is the results visualization. Crop breeders, in terms of comprehensibility and visual quality, look for alternatives to conventional methods. The main method to exhibit the combining abilities of parents and crosses among various developed graphical methods is the genotype + genotype $\times$ environment (GGE) biplot analysis. The GGE biplot has extensively been used to study the GCA and SCA in a cross and identifying best cross combinations for diallel data (Anido et al. 2004; Bertoia et al. 2006; Darvishzadeh et al. 2009; Vivek et al. 2010). But such studies have been less done for line $\times$ tester data (Fotokian and Agahi 2014; Kahriman et al. 2016; Kannababu et al. 2017; Ruswandi et al. 2015).

This research was carried out to (i) assess combining ability of some maize inbred lines and testers by the GGE biplot analysis for graphical interpretation of the line $\times$ tester data for maize grain yield, (ii) identify most efficient testers and classify inbred lines into heterotic groups using GGE biplot and (iii) to compare the traditional Kempthorne's line $\times$ tester analysis procedure and GGE biplot procedure.

\section{MATERIAL AND METHODS}

In line $\times$ tester fashion, five female inbred lines [KLM77002/3-1-1-1-1-1-1-3(L1), KLM78012/6-1-1-1-1-2(L2), KLM81027(L3), KLM77029/8-1-1-1-2-2-2(L4), KLM76021/1-3-1-1-1-2-1-1(L5)] and three male testers [K18(T1), K47/3(T2) and B73(T3)] were crossed through controlled pollination to produce 15 test-crosses in field of Agricultural and Natural Resources Research Centre of Ardebil Province (Moghan) in 2017.

In the year 2018, these test-crosses tested in the field for yield performance and other agronomic traits in seven regions of Iran including Karaj (35.81 E, 50.95 N), Moghan (47.32 E, 39.41 N), Shiraz (52.60 E, 29.56 N), Kermanshah (47.26 E, 34.80 N), Kerman (56.36 E, 28.45 N), Esfahan (51.52 E, 34.31 N) and Miyandoab (46.03 E, 36.58 N).

The experiment was organized as a randomized complete block design with three replications. Each plot involves two rows of $5.6 \mathrm{~m}$ in length with a spacing of $0.75 \mathrm{~m}$ between rows and $0.35 \mathrm{~m}$ between holes, including two plants in each. The population density was approximately 74500 plants $\cdot \mathrm{ha}^{-1}$. Data was collected on grain yield (GY) $\left(\mathrm{t} \cdot \mathrm{ha}^{-1}\right)$ for each test-cross was adjusted to $14 \%$ grain moisture content. Based on recommendations for each site, crop management and protection practices were applied.

The estimation of GCA and SCA effects was done by the traditional Kempthorne's line $\times$ tester analysis procedure (Kempthorne 1957) and GGE biplot procedure. Genotype + genotype $\times$ environment biplots are generally utilized to analyze two-way data, in which rows and columns represent different experimental units (Yan and Hunt 2002). Towards a generalized application of the GGE biplot line $\times$ tester data, the row is considered as a "line" and the column as a "tester" (Yan and Hunt 2002). When the GGE biplot is used to analyze line $\times$ tester data, the average yield is correspondent to GCA and stability of the genotypes is regarded as SCA, respectively, of the parents. Contrary to conventional numerical line $\times$ tester analysis where SCA relates to a cross, in the GGE biplot SCA represents that of parental lines. The mathematical model for the GGE biplot analysis of the line $\times$ tester data has been elaborated by Ruswandi et al. (2015). Data were analyzed using GGE biplot software (Yan et al. 2001).

\section{RESULTS AND DISCUSSION}

According to the pooled analysis of variance, crosses showed significant differences for grain yield. Also, the differences observed among the testers, inbred lines, and interactions for the line $\times$ tester, crosses $\times$ environments, line $\times$ tester $\times$ environment was significant (Table 1).

The significant interactions suggest that differences among inbred lines, testers, and crosses are not constant from one site to another. This type of interaction is more common and inevitable in agricultural and biological investigations (Yan and Kang 2002). 
The test-crosses $\mathrm{L} 1 \times \mathrm{K} 18\left(11.72 \mathrm{t} \cdot \mathrm{ha}^{-1}\right)$ and $\mathrm{L} 4 \times \mathrm{K} 18\left(11.69 \mathrm{t} \cdot \mathrm{ha}^{-1}\right)$ were high yielding test-crosses, indicating the possibility of obtaining high yielding hybrid(s) (data didn't present in the table).

Estimates of GCA effects for grain yield by the traditional Kempthorne's line $\times$ tester analysis procedure showed that there were significant changes in the magnitude and rank of GCAs from one environment to another. However, the inbred line L4 had positive GCA effect in the most of environments, with an average of 0.73 , whereas the inbred line L5 exhibited

Table 1. Combined analysis of variance for grain yield.

\begin{tabular}{|c|c|c|}
\hline Variation sources & DF & Mean squares \\
\hline Environment (E) & 6 & $111.87^{\star \star}$ \\
\hline Replications/E & 14 & 7.79 \\
\hline Crosses (C) & 14 & $16.67^{\star \star}$ \\
\hline LGCA [Lines (L)] & 4 & $13.04^{\star \star}$ \\
\hline TGCA [Testers (T)] & 2 & $64.34^{* *}$ \\
\hline $\mathrm{T} \times \mathrm{L}, \mathrm{SCA}$ & 8 & $6.56^{* *}$ \\
\hline $\mathrm{C} \times \mathrm{E}$ & 84 & $4.36^{\star \star}$ \\
\hline$L G C A \times E$ & 24 & $4.95^{\star \star}$ \\
\hline $\mathrm{TGCA} \times \mathrm{E}$ & 12 & $5.12^{\star *}$ \\
\hline $\mathrm{SCA} \times \mathrm{E}$ & 48 & $3.88^{\star *}$ \\
\hline Error & 196 & 2.12 \\
\hline
\end{tabular}

**Significant at $1 \%$ probability level.

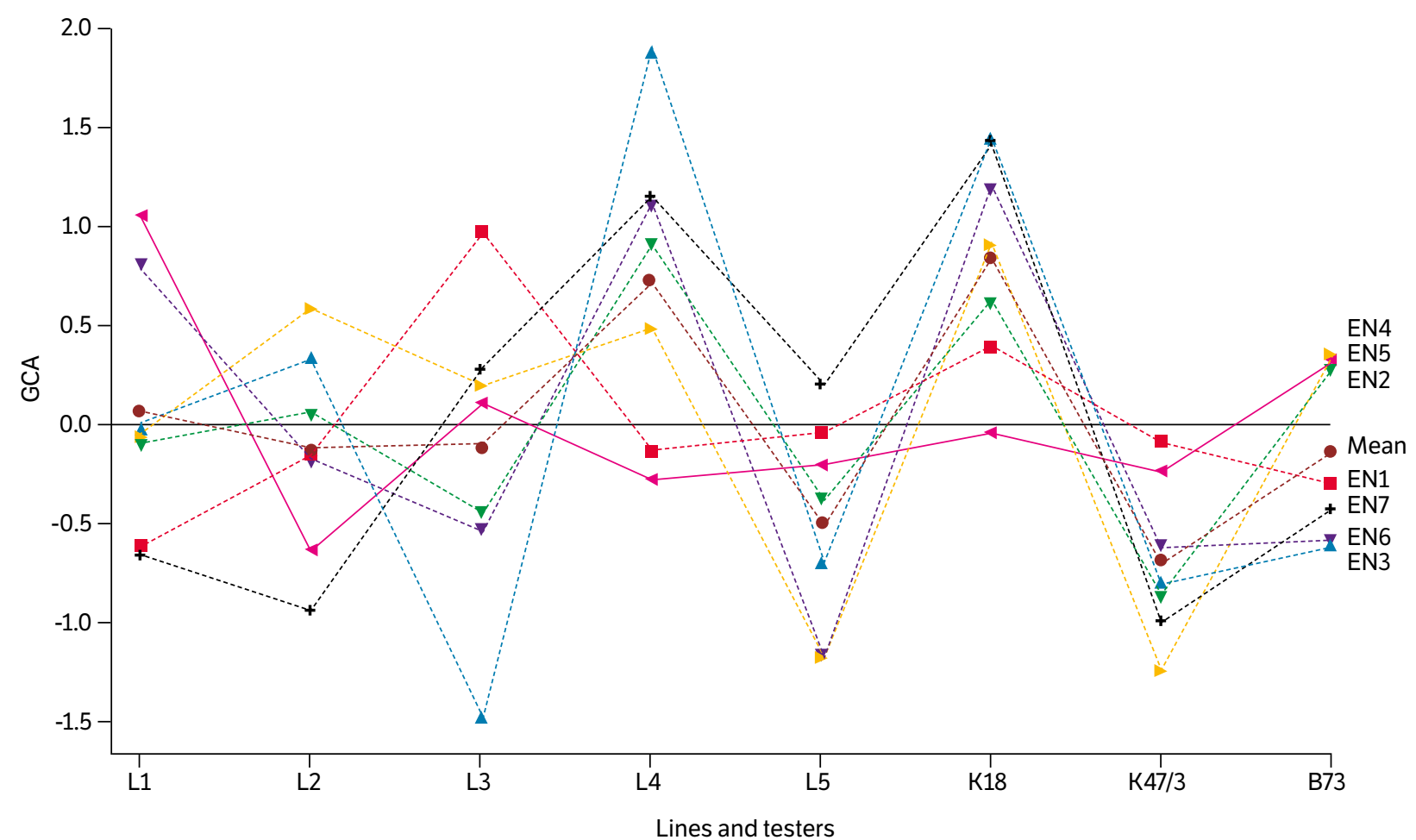

$\mathrm{K} 18, \mathrm{~K} 47 / 3$, and B73 were testers in the study. L1, L2, L3, L4 and L5, were inbred lines in the study, named KLM77002/3-1-1-1-1-1-1-3, KLM78012/6-1-1-1-1-2, KLM81027, KLM77029/8-1-1-1-2-2-2, KLM76021/1-3-1-1-1-2-1-1, respectively.EN1, EN2, EN3, EN4, EN5, EN6, and EN7 referred to Karaj, Moghan, Shiraz, Kermanshah, Kerman, Esfahan, and Miyandoab environments, respectively.

Figure 1. General combining ability (GCA) of inbred lines and testers for grain yield. 
the lowest GCA effect in the most of environments, with an average of -0.51 (Fig. 1), indicating the existence of the best and poorest general combiners in the set of the studied inbred lines, respectively. Inbred lines had high potential to transfer desirable traits to their hybrids; identified for good general combining ability could be utilized to improve top hybrids in maize breeding programs. From the tester, K18 was the best general combiner while K47/3 was the poorest general combiner for grain yield across environments (Fig. 1).

Based on the results of this study, SCA effects estimates among the test-crosses were both negative and positive for grain yield. Also, changes in the magnitude and rank of SCAs were observed from one environment to another; however, testcrosses $\mathrm{L} 1 \times \mathrm{B} 73$ and $\mathrm{L} 1 \times \mathrm{K} 47 / 3$ were best and poor specific combiner across environments for grain yield, respectively (Fig. 2). Observed highly significant SCA effects for the test-crosses were predictable according to the significant deviation of their parental performances. The crosses with positive and significant SCA effects could be selected to use in maize breeding programs for their specific combining ability.

The first two components of the GGE biplot model justified 80.8\% (71.5\% for PC1 and 9.3\% for PC2) of the total variation in grain yield of the test-crosses (Figs. 3-6), indicating the application of GGE biplot model for the line $\times$ tester data were highly sufficient. According to Yan and Hunt (2002), predictions based on the biplot will be more accurate when the high variation explained by the biplot.

Applying of the polygon view of GGE biplot model generated visual display of the interaction pattern among the studied inbred lines and testers for the line $\times$ tester data (Fig. 3), so that the best mating partner for each of the testers and as well the best hybrid(s) identified. The inbred line at a vertex of the polygon is considered a good mating partner for the testers falling in that sector, and the best cross combination would be between the tester farthest from the origin and the inbred line at the vertex of the polygon, i.e., the inbred lines settled close to the origin of the polygon were less responsive to the different testers than other inbred lines within the respective sectors. Furthermore, the vertex inbred lines, which fell no

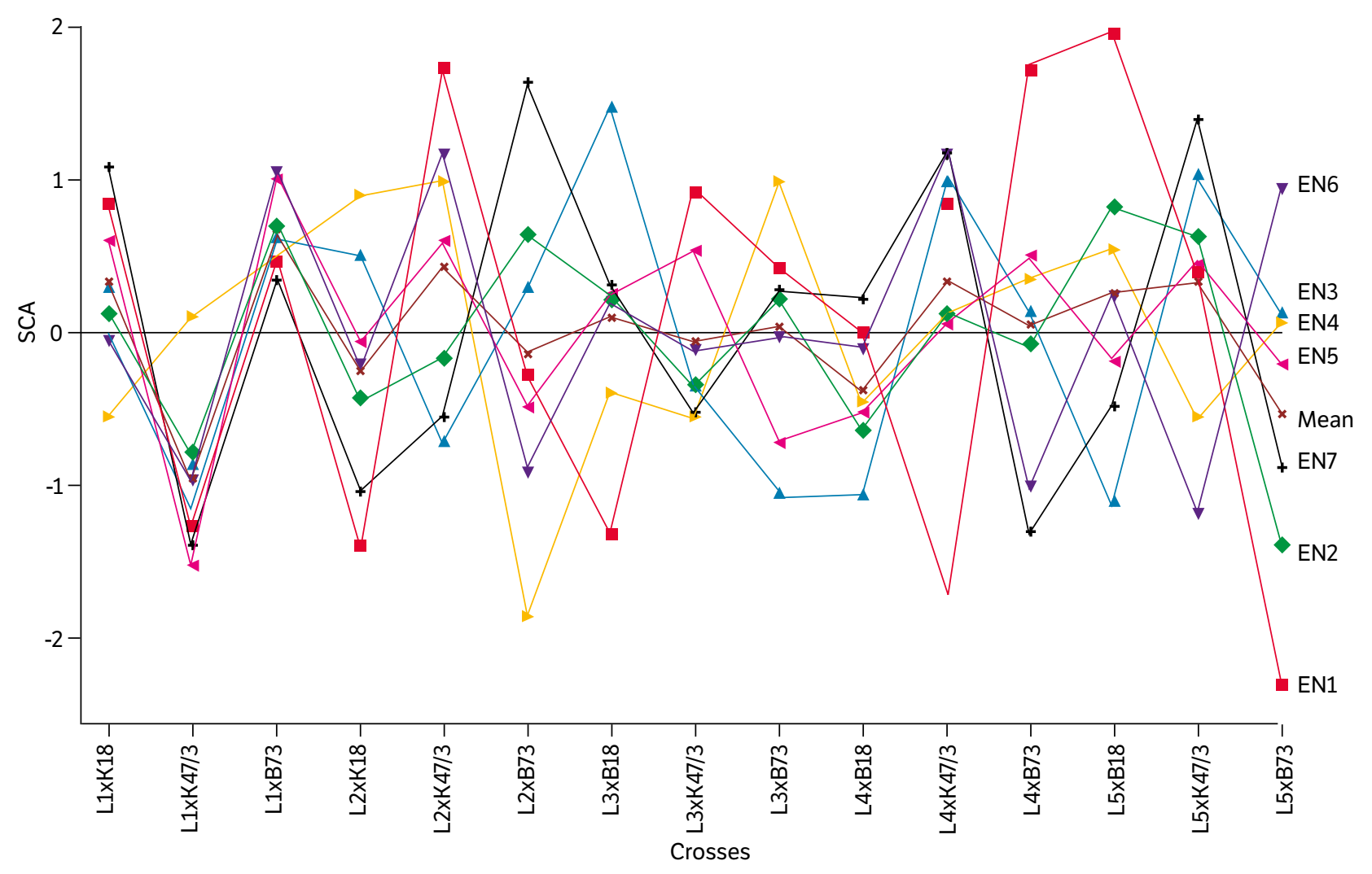

Figure 2. Specific combining ability (SCA) of crosses for grain yield. (For figure details, refer to the caption of Fig. 1.) 


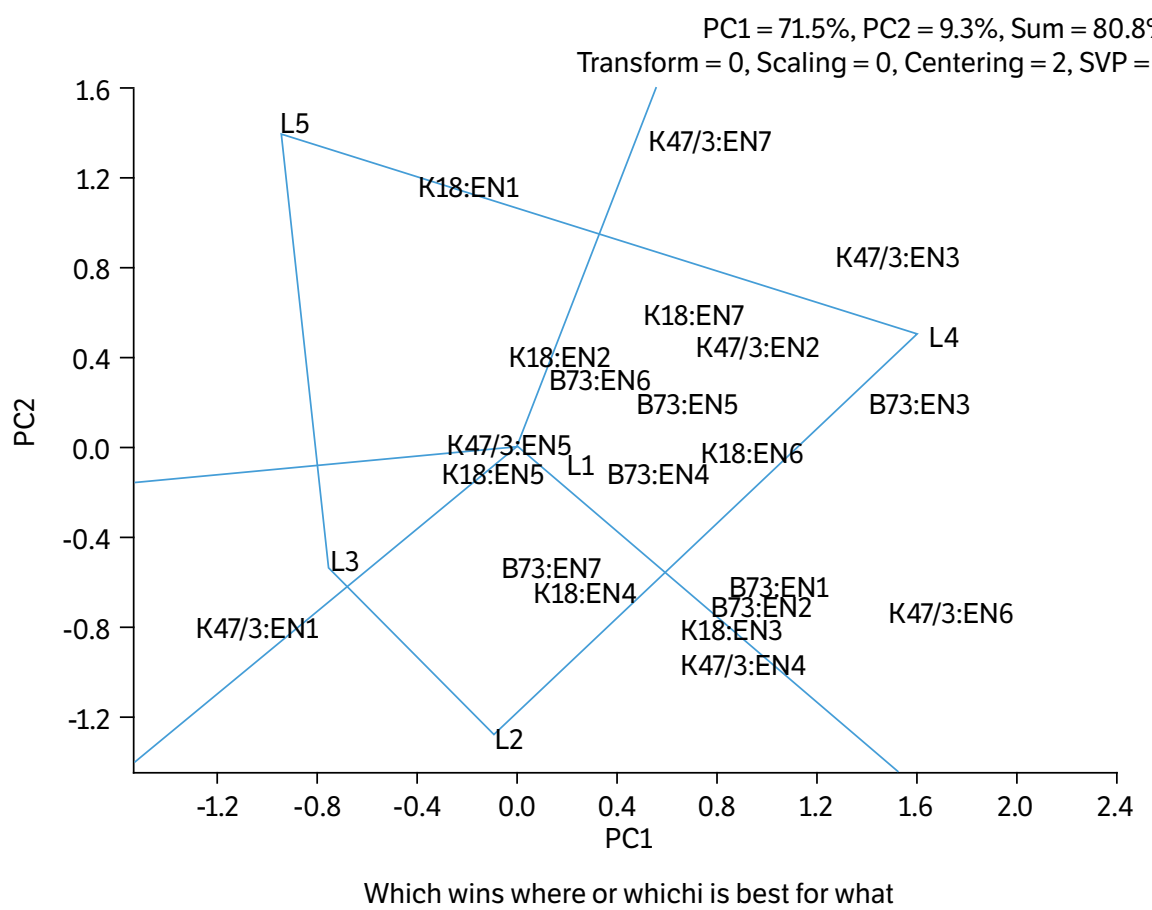

Figure 3. A polygon view of the line $\times$ tester data showing the best mating partners for the different testers over the seven environments. (For figure details, refer to the caption of Fig. 1. )

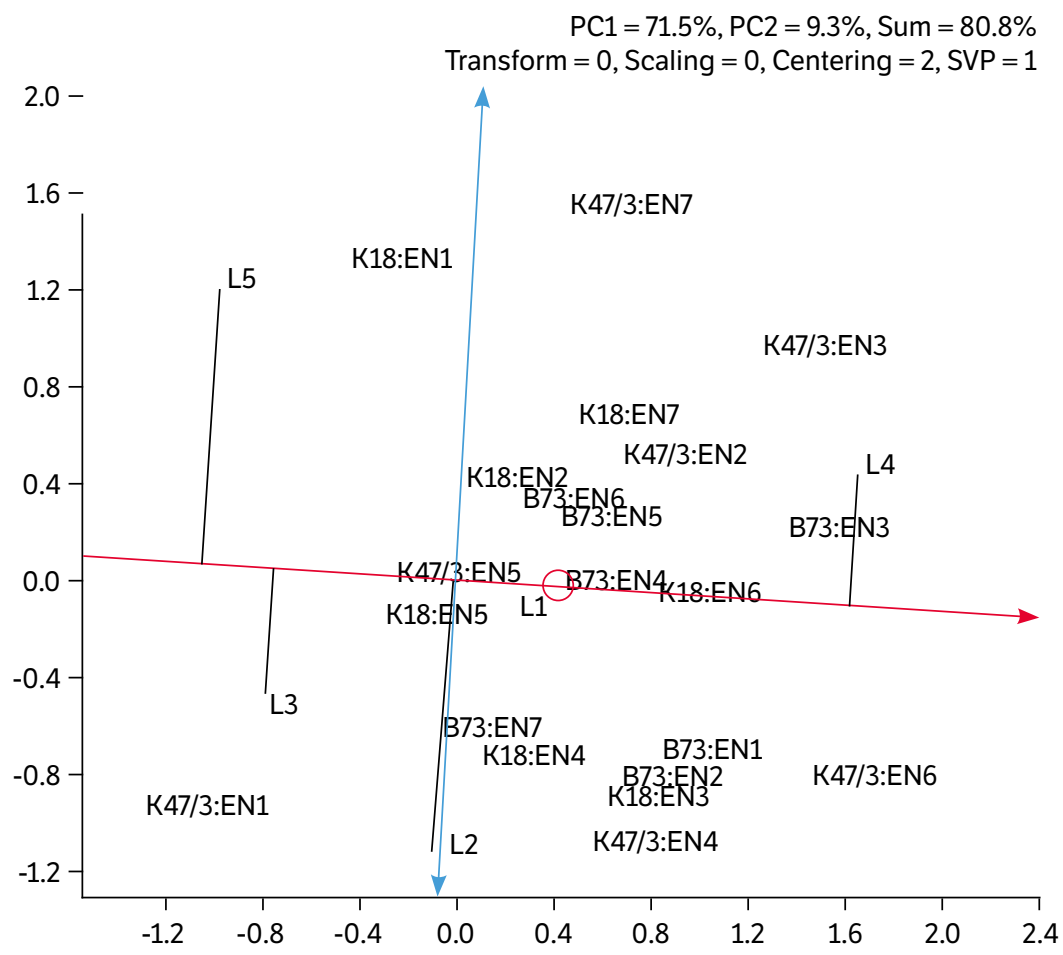

Figure 4. The vector view of the GGE biplot showing the best inbred lines based on GCA effects over the seven environments. (For figure details, refer to the caption of Fig. 1. ) 


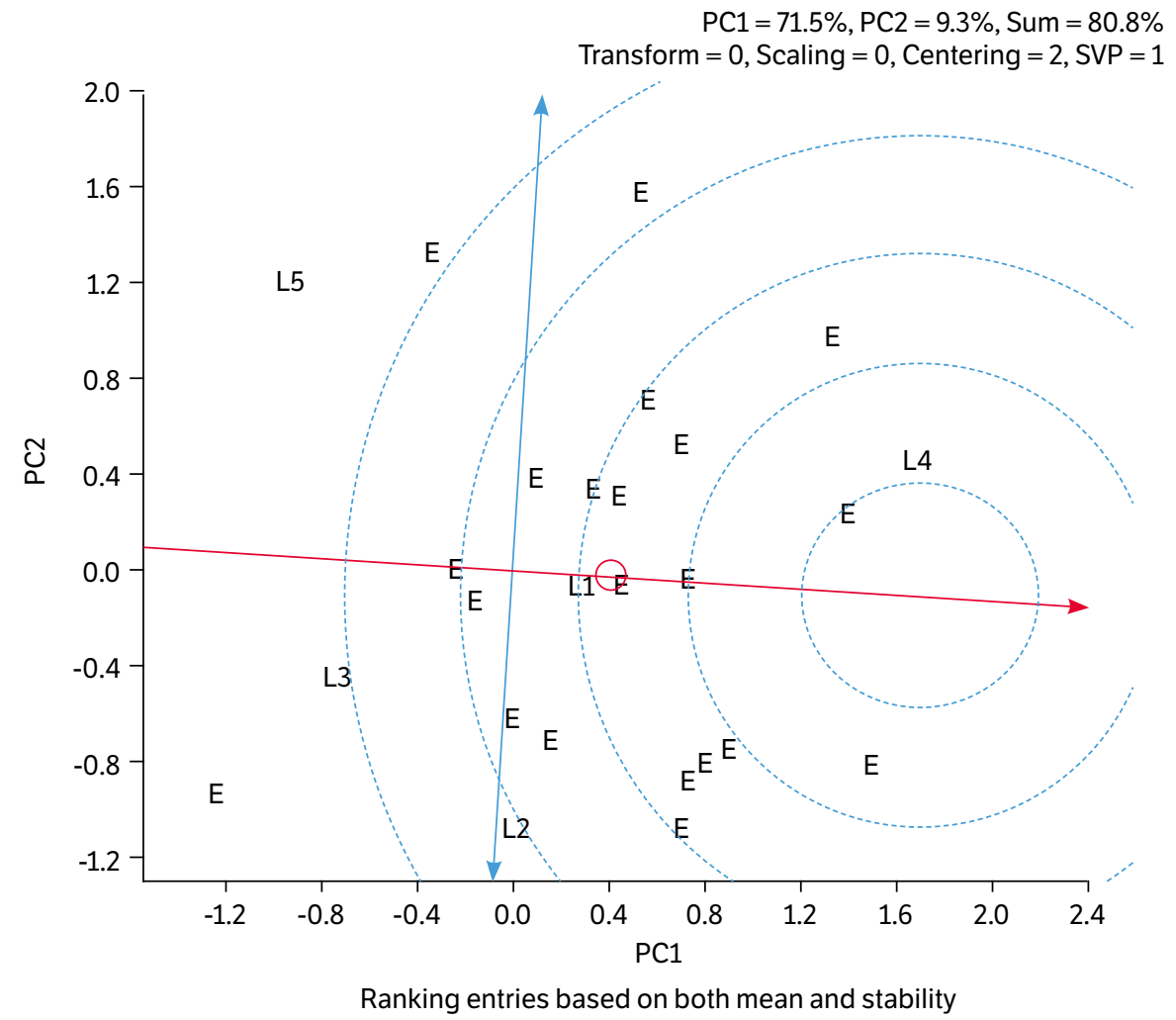

Figure 5. The vector view of the GGE biplot showing the best inbred lines based on GCA effects over the seven environments. (For figure details, refer to the caption of Fig. 1. )

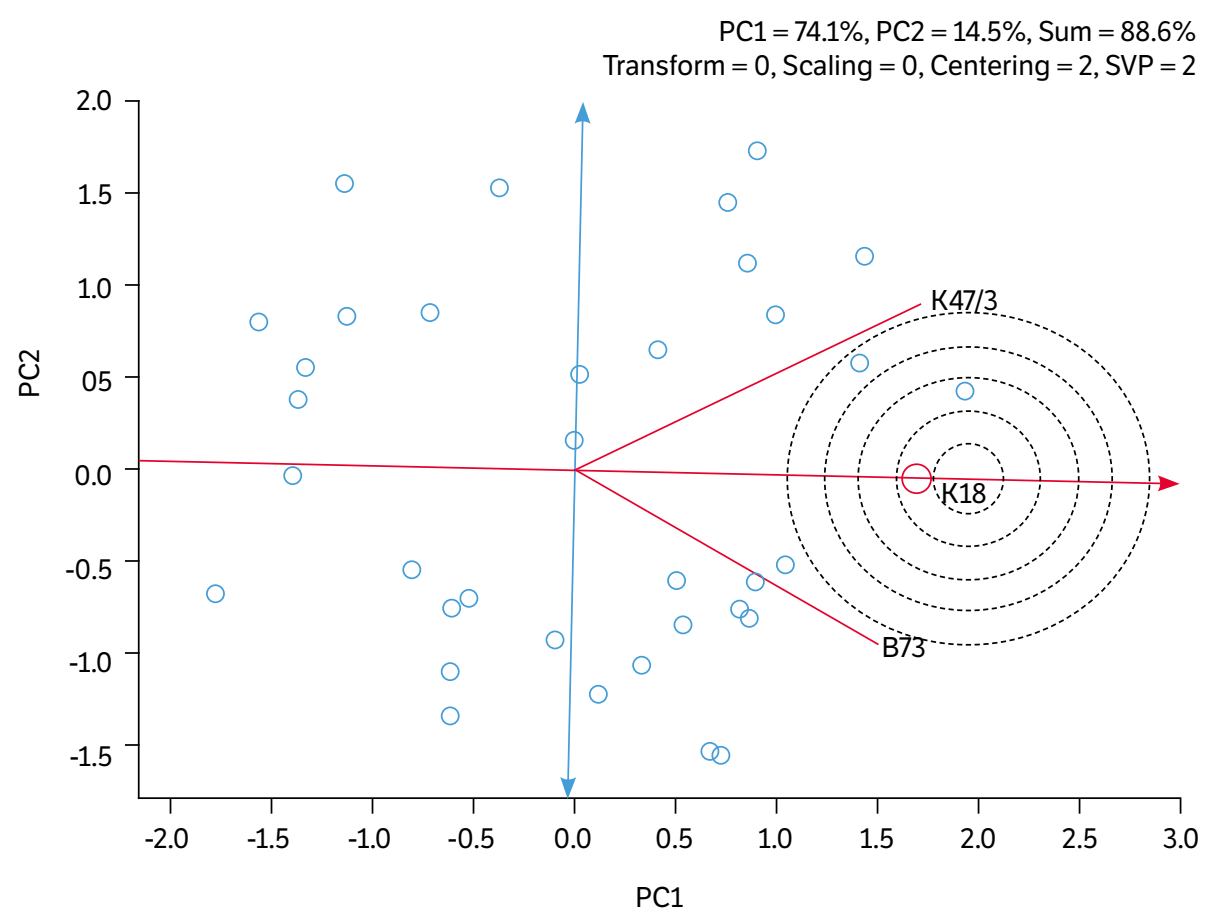

Rankimg testers based on both discriminating ability and representativeness

Figure 6. The vector view of the GGE biplot showing the ideal testers based on the discriminating power and representativeness of the testers over the seven environments. 
testers in their respective sectors, weren't good mating partners with any of the testers and were not responsive. Inbred lines L4, L5, L3, and L2, which located farthest from the origin, were vertex inbred lines and defined the polygon (Fig. 3). Locating four of the five inbred lines in the vertex indicated that there was a large genetic distance among the inbred lines.

Distributing the performance of a test-cross in the different environments at the different areas of the polygon referred to the being of interaction effects. The inbred line L4 in six of the seven environments (except EN7) had positive and high combining ability with B73 tester, among which the highest combining ability was observed in EN3 environment. Also, the inbred lineL4 with the tester $\mathrm{K} 47 / 3$ had a positive combining ability in four environments, which the highest combining ability for it in EN3, EN4, and EN6 environments. However, this inbred line had a high and negative combining ability with the tester K47/3 in EN3 environment. In addition, the inbred line L4 with the tester K18 had the positive and the close to zero combining ability in the most of environments. Also, K18 tester had positive but low combining ability with L2 and L5 in EN4 and EN1 environments. In general, it seems that the inbred line L4 combined well with the testers K47/3 and B73, which showed that there was the large genetic distance between the two these testers with that inbred line, whereas the inbred lines L5 and L2 did not combine well with any one of the testers. Thus, the best hybrid combinations were L4 $\times \mathrm{K} 47 / 3$ and L4 $\times$ B73 (Fig. 3). In the study done by Taheri Tarigh et al. (2017), the testers K47/3 and B73 were assigned to the same heterotic group, that confirmed the result of the present study.

The GCA effect of an entry is estimated by the value of its cross with the mean tester and is approximated by its projections on to the average tester coordinate (ATC) abscissa (single-headed arrow line). Therefore, Fig. 4 indicated that the inbred line L4 had the highest GCA effect whereas the inbred line L5 had the lowest GCA effect for grain yield. The GCA ranks of inbred lines were as L4 > L1 > L2 > L3 > L5. The ATC ordinate (double-headed arrow line) separated the inbred lines with positive and negative PCA scores from each other. Thus, the inbred lines L4 and L1 had a positive GCA effect for grain yield. Graphically displaying the ideal inbred line is another utility of the GGE biplot model for the line $\times$ tester data. An ideal inbred line should take place in the center of the concentric circles (Fig. 5). Based on Fig. 5, the inbred line L4 located relatively in the center of the concentric circles and was the ideal inbred line in case of combining ability for grain yield. Thus, it would be recommended that the inbred line L4 would more be tested in new hybrid combinations to release high potential hybrid. Locating all the three testers on the same side of the ATC ordinate indicated that the GCA effect of the testers was significantly large so that the testers were able to classify the inbred lines into distinct heterotic groups. Considering the orthogonal property of GCA and SCA, the projections of the entry on to the ATC ordinate estimates SCA (Yan and Hunt 2002) which indicates the tendency of the entries to produce superior hybrids with specific testers. A greater projection onto the ATC ordinate indicates a greater SCA effect. Thus, the SCA effects of the entries were ordered as L5 $>$ L2 > L4 > L3 > L1 for grain yield (Fig. 4).

According to the results of this study, the obtained result for the line $\times$ tester data using GGE biplot was similar to those derived from the Kempthorne's line $\times$ tester analysis method for grain yield (Figs. 1, 3 and 4).

An ideal tester should have the longest vector of all testers (i.e., be most discriminating) and have zero projection onto the ATC ordinate (i.e., be most representative of testers). Such a tester should be in the center of the concentric circles. Thus, the closer a tester's marker was to the ideal tester, the better it was. The biplot showed that the tester K18 had the longest vector, thus it had the highest discriminating power and was the most representative. Also, this tester was the closest tester to the center of the concentric circle, Thus, the tester K18 should be considered as an ideal (best) tester among the three. Furthermore, the discriminating power of the testers was ordered as K18 $>$ K47/3 > B73 based on the vector length of testers (Fig. 6).

The results presented in this study were consistent with the finding of Fotokian and Agahi (2014), Ruswandi et al. (2015), Badu-Apraku and Akinwale (2019) and Amiri-Oghan et al. (2018) in case of comparing biplot analysis of the line $\times$ tester data and Kempthorne's analysis of the line $\times$ tester data.

Heterotic groups were identified using the average tester ordination view of the GGE biplot. From the biplot display in Fig. 4, two distinct heterotic groups could be identified among the inbred lines. Group 1 comprised the inbred lines L4 and L5, while group 2 consisted of the inbred lines L2 and L3 (Fig. 4). The shortcoming of the GGE biplot in defining heterotic groups of inbred lines is that it can only detect two distinct heterotic groups and puts the rest in the third group even when there are more groups (Yan and Kang 2002). 


\section{CONCLUSION}

The results of this study revealed that grain yield was controlled by both additive and nonadditive of gene action, so that selection among promising hybrids as well selection of high-performance inbred lines in segregating generations could be used in maize hybrid development.

Considering the importance of additive gene effect than the nonadditive for grain yield, it could be possible to classify the studied inbred lines into heterotic groups by the used testers. The obtained results for the combining ability of the inbred lines and testers by the GGE biplot were in close agreement with those of the conventional line $\times$ tester procedure, thus validating the GGE biplot as a veritable statistical tool to estimate the combining ability of the inbred lines for the linex tester data. Furthermore, the GGE biplot procedure is able to estimate the discriminating power of the testers, which is not readily achievable by the conventional line $\times$ tester method. The inbred line L4 was recognized as outstanding for its GCA effect and the tester K18 was highly efficient based on its discriminating power.

Finally, it can be concluded that the test-crosses of $\mathrm{L} 4 \times \mathrm{K} 47 / 3$ and $\mathrm{L} 4 \times \mathrm{B} 73$ are suggested to release high grain yield hybrids.

\section{AUTHOR'S CONTRIBUTION}

Conceptualization: Shiri M. and Momeni H.; Methodology: Shiri M. and Momeni H.; Investigation: Shiri M. and Momeni H.; Formal Analysis: Shiri M. and Momeni H.; Writing - Original Draft: Shiri M. and Momeni H.; Writing Review and Editing: Shiri M.; Funding Acquisition: Momeni H.; Resources: Shiri M.; Supervision: Majidi Hervan E.; Shiri M.; Khosrowshahli M.

\section{REFERENCES}

Amiri-Oghan, H., Shariati, F., Sabaghnia, N., Alizadeh, B., Millner, J., Rad, A. H. S. and Gholamhoseini, M. (2018). Combining ability and heterosis for some canola characteristics sown on recommended and late planting dates using biplot. Acta Agriculturae Slovenica, 111 , 419-429. https://doi.org/10.14720/aas.2018.111.2.16

Anido, F. L., Cravero, V., Asprelli, P., Firpo, T., García, S. M. and Cointry, E. (2004). Heterotic patterns in hybrids involving cultivar-groups of summer squash, Cucurbita L. Euphytica, 135, 355-360. https://doi.org/10.1023/B:EUPH.0000013373.91446.f3

Badu-Apraku, B. and Akinwale, R. O. (2019). Biplot analysis of line $\times$ tester data of maize (Zea mays L.) inbred lines under stress and nonstress environments. Cereal Research Communications, 47, 518-530. https://doi.org/10.1556/0806.47.2019.25

Bertoia, L., López, C. and Burak, R. (2006). Biplot analysis of forage combining ability in maize landraces. Crop Science, 46, $1346-1353$. https://doi.org/10.2135/cropsci2005.09-0336

Darvishzadeh, R., Bernousi, I., Kiani, S. P., Dechamp-Guillaume, G. and Sarrafi, A. (2009). Use of GGE biplot methodology and Griffing' $\mathrm{s}$ diallel method for genetic analysis of partial resistance to phoma black stem disease in sunflower. Acta Agriculturae Scandinavica, Section B - Soil \& Plant Science, 59, 485-490. https://doi.org/10.1080/09064710802282747

Edwards, L. H., Ketata, H. and Smith, E. L. (1976). Gene action of heading date, plant height and other characters in two winter wheat crosses. Crop Science, 16, 275-277. https://doi.org/10.2135/cropsci1976.0011183X001600020029x

Fotokian, M. H. and Agahi, K. (2014). Biplot analysis of genotype by environment for cooking quality in hybrid rice: a tool for line $\times$ tester data. Rice Science, 21, 282-287. https://doi.org/10.1016/S1672-6308(13)60193-6

Iqbal, A. M., Nehvi, F. A., Wani, S. A., Qadir, R. and Dar, Z. A. (2007). Combining ability analysis for yield and yield related traits in maize (Zea mays L.). International Journal of Plant Breeding and Genetics, 1, 101-105. https://doi.org/10.3923/ijpbg.2007.101.105 
Kahriman, F., Egesel, C. Ö., Orhun, G. E., Alaca, B. and Avci, F. (2016). Comparison of graphical analyses formaize genetic experiments: Application of biplots and polar plot to line $\times$ tester design. Chilean Journal of Agricultural Research, 76,285-293. https://doi.org/10.4067/S0718-58392016000300004

Kannababu, N., Rakshit, S., Madhusudhana, R., Tonapi, V. A., Das, I. K. and Raghunath, K. (2017). Identification of superior parental lines for seed quality and storability through GGE biplot analysis of line $\times$ tester data in grain sorghum. Indian Journal of Genetics and Plant Breeding, 77, 278-286. https://doi.org/10.5958/0975-6906.2017.00037.2

Kempthorne, O. (1957). An introduction to genetic statistics. Hoboken: John Wiley \& Sons.

Malvar, R. A., Ordás, A., Revilla, P. and Cartea, M. E. (1996). Estimates of genetic variances in two spanish populations of maize. Crop Science, 36, 291-295. https://doi.org/10.2135/cropsci1996.0011183X003600020013x

Nduwumuremyi, A., Tongoona, P. and Habimana, S. (2013). Mating designs: helpful tool for quantitative plant breeding analysis. Journal of Plant Breeding and Genetics, 1, 117-129.

Nevado, M. E. and Cross, H. Z. (1990). Diallel analysis of relative growth rates in maize synthetics. Crop Science, 30, 549-552. https:// doi.org/10.2135/cropsci1990.0011183X003000030015x

Ruswandi, D., Suprianta, J., Waluyo, B., Makkulawu, A. T., Suryandi, E., Chindy, Z. U. and Ruswandi, S. (2015). GGE biplot analysis for combining ability of grain yield and early maturity in maize mutant in Indonesia. Asian Journal of Crop Science, 7, 160-173. https://doi. org/10.3923/ajcs.2015.160.173

Shiri, M., Aliyev, R. T. and Choukan, R. (2010). Water stress effects on combining ability and gene action of yield and genetic properties of drought tolerance indices in maize. Research Journal of Environmental Sciences, 4, 75-84. https://doi.org/10.3923/rjes.2010.75.84

Shiri, M. R., Choukan, R. and Aliyev, R. T. (2014). Study of genetic diversity among maize hybrids using SSR markers and morphological traits under two different irrigation conditions. Crop Breeding Journal, 4, 65-72. https://doi.org/10.22092/cbj.2014.109674

Shiri, M. (2017). The performance of temperate maize testers for screening of tropical and subtropical germplasm. Journal of Crop Breeding, 9, 85-94. https://doi.org/10.29252/jcb.9.23.85

Shiri, M. and Ebrahimi, L. (2017). The selection of maize lines derived from CIMMYT germplasm through combining ability with temperate testers. Cereal Research, 7, 101-114. https://doi.org/10.22124/c.2017.2431

Taheri Tarigh, S., Ramezapour,S. S., Choukan, R., Soltanloo, H., Navabpour, S. and Guilani, K. (2017). Combining ability of maize lines from tropical and subtropical germplasm using temperate testers. Seed Plant Improvement Journal, 33, 299-314. https://doi.org/10.22092/spij.2017.116679

Vivek, B. S., Odongo, O., Njuguna, J., Imanywoha, J., Bigirwa, G. and Pixley, K. (2010). Diallel analysis of grain yield and resistance to seven diseases of 12 African maize (Zea mays L.) inbred lines. Euphytica, 172, 329-340. https://doi.org/10.1007/s10681-009-9993-5

Yan, W., Cornelius, P. L., Crossa, J. and Hunt, L. A. (2001). Two types of GGE biplots for analyzing multi-environment trial data. Crop Science, 41, 656-663. https://doi.org/10.2135/cropsci2001.413656x

Yan, W. and Hunt, L. A. (2002). Biplot analysis of diallel data. Crop Science, 42, 21-30.

Yan, W. and Kang, M. S. (2002). GGE biplot analysis: a graphical tool for breeders, geneticists and agronomists. Boca Raton: CRC Press. https://doi.org/10.1201/9781420040371

In the article The usefulness of GGE biplot methodology for line $\times$ tester data of maize inbred lines with DOI: https://doi.org/10.1590/1678-4499.20200130, published in Bragantia vol.79 no.4 Campinas Oct./Dec. 2020:

In the footline where is read Bragantia, Campinas, v. 79, n. 4, p.412-420, 2020 should be read Bragantia, Campinas, v. 79, n. 4, p.537-545, 2020. 